\title{
Role of Biofilm on Granular Wood Charcoal in Enhancing Primary Wastewater Treatment for Irrigation Reuse
}

\author{
Ahmed A. El-Refaey ${ }^{1}$
}

\begin{abstract}
Increasing water scarcity necessitates safe reuse to narrow the gap between demand and supply of irrigation water. This study investigated the role of biofilm on two different particle sizes $(0.5-1 \mathrm{~mm}$ and $1-2 \mathrm{~mm})$ of granular wood charcoal (GWC) in enhancing the effluent quality of primary wastewater treatment to develop a cost-effective wastewater treatment method. Granular wood charcoal (GWC) was characterized by surface area, pore volume, fourier transforminfrared (FTIR) and scanning electronmicroscopy (SEM) to demonstrate the physicochemical properties. Bench scale column experiments were conducted for the two different particle sizes column (1), 0.5 - 1mm, and column (2), 1-2 mm, with an average flow rate of $10 \mathrm{~cm}^{3} / \mathrm{min}$ and $6.54 \mathrm{~h}$ as average empty bed contact time (EBCT). GWC biofilm formation was confirmed by SEM examination in voids and channels and on surfaces of the GWC. The role of biofilm on the GWC has demonstrated consistently removal organic matter as chemical oxygen demand (COD). COD was monitored with time and extended to 96 day to examine the performance of the biofilter column. COD tended to decrease with time for both columns. Slight increase in the removal efficiency of COD with time in column1 (91.36 \%) in comparison to that of column $2(87.69 \%)$ was observed. Such in crease could be due to difference in surface area of the two particles size. Effluent can be characterized as slight to moderate degree of guideline restriction in irrigation reuse for salinity and sodicity for both columns. For safe irrigation reuse, addition disinfection step may be needed even with obtained results of Escherichia coli $(E$. coli) removal efficiency more than $99 \%$. The results indicated that biofilter process can be an efficient option for upgrading the primary wastewater treatment method.
\end{abstract}

Key words: Granular wood charcoal, biofilm, Wastewater, Chemical Oxygen Demand

\section{INTRODUCTION}

Egypt is facing severe water scarcity combined with the enormous challenges of population growth, and increasing food demand. It is imperative to reclaim wastewater to benefit public health, water pollution control, and irrigation reuse, especially with limited water resources. Water reuse has been dubbed as the greatest challenge of the $21^{\text {st }}$ century (Metcalf and Eddy, 2003); and a paradigm shift from effluent disposal to water reuse is needed. In Egypt, the treated wastewater amounts about 3 billion $\mathrm{m}^{3} /$ year, mostly discharged to drains; with about 0.8 billion $\mathrm{m}^{3} /$ year disposed of to lakes, sea, and desert.The total quantity of reused treated wastewater in Egypt is estimated to be about $0.3 \mathrm{BCM}$ in 2013(MWRI, 2014). The main impediment to irrigation reuse is that the treated effluents do not meet the stringent standards for disposal into irrigation canals.

A cost-effective approach is needed to clean large volumes of wastewater often discharged into surface waters (Jowett and McMaster, 1995; Agbanobi, 1999). Conventional wastewater treatment consists of amixture of physical, chemical, and biological processes and performances to remove solids, organic matter and nutrients from wastewater. In primary treatment, a physical operation, usually sedimentation is used to remove the floating and settleable materials found in wastewater. However, resulting achieved in primary treatment is the removal of portion of the suspended solids (50 to 70 percent) and organic matter (25 to 40 percent) from the wastewater (Masters, 1998; Metcalf and Eddy, 2003).

In view of the economic reality, it is crucial to develop a simple and cost-effective system to reclaim wastewater for pollution control and irrigation reuse especially in rural areas. One of the options for enhancing primary treatment is biofiltration technology. Biofiltration can be defined as" a biological pollution control technology that uses active microbial populations attached to a solid media to degrade pollutant" (Swanson and Loehr, 1997). Biofiltration is one of the most important separation processes that can be used to remove organic pollutants from air, water, and wastewater (Chaudhary et.al, 2003; Emelko et. al, 2006). The process relies on the mechanisms of adsorption, biodegradation, convection and diffusion (Swanson and Loehr, 1997; Liang et al., 2007). Contact time, mass loading, surface loading and removal efficiency are important design and performance parameters. Also, media properties, temperature, $\mathrm{pH}$, toxicity, microorganisms, and acclimation are factors requiring careful consideration in the design and operation of the biofilter (Swanson and Loehr, 1997).

${ }^{1}$ Department of Soil \& Water Science, Faculty of Desert

and Environmental Agriculture,

Alexandria University (Matrouh Branch), Egypt

E-mail: ahmedelrefaey@alexu.edu.eg

Received December 4, 2016, Accepted December 27, 2016. 
Selecting the proper biofilter medium is an important step toward developing a successful biofiltration operation. Absorbent filter particles should combine, a light weight aggregate, low-density granules, large pore volumes with high surface areas, economical cost and is therefore an ideal growing medium. The physical properties of solid particles impose natural limits to microbial attachment means, contact time, aeration and therefore limit treatment performance. The performance of a biofilter column relies on the biomass attached to the media. The biomass development and its maintenance on surface of the media, on the other hand, relay generally on surface characteristics of the filter media itself (Chaudhary, 2003).Charcoal adsorbent has long being known as one of the most effective technologies at removing natural organic matter from water and wastewater. The good suitability recognized because of its large specific surface area and well developed porous structure, which provide a high sorption capacity towards organic molecules (Putz et al., 2005; Emelko et al., 2006; Seredyńska-Sobecka et.al, 2006; Aktaş and Çeçen, 2007; Buchanan et al., 2008; Simpson, 2008).

Charcoal surface can be occupied by microorganisms which may finally create active biofilm (Kasuga et al., 2007; Huang and Chen, 2004; Velten et al., 2011). Biomasses attached onto the media as biofilm oxidize most of the organics and utilize it as an energy supply and carbon source (Chaudhary et al., 2003). Biofilm composition and activity are two important parameters for the successful process and manage of fixed film processes in water and wastewater treatment. The biofilm composition is a function of physicochemical conditions, as well as cell morphology (Lazarova and Manem, 1995). Derlon et al. (2013) reported that the increase of the soluble fraction in organic substrate increased biofilm accumulation on membrane surface. However, the rate and quantity of biofilm structure depends on a lot of factors including water quality, type of filter media, hydrauliccircumstances, temperature, backwashing management, among others(Zhu et al., 2010; Urfer and Huck, 2001; Velten et al., 2011).

The limitations associated with decreasing the efficiency of the biofilm in biofilter columns are clogging of biofilters and saturation of packing media with organic matter overtime(considered to be "exhausted" (Scholz and Martin, 1997)). Applying periodic backwashes will prevent the progressive irreversible clogging of biofilter columns and recovery of the hydraulic performance and ensure long-term performance of the biofilters(Zhuet al., 2010; Zheng et al., 2011; Putz et al., 2005). Since, backwashing does not get rid of organic matter adsorbed to the granular particles; the exhausted media should be replaced or thermally regenerated in order to restore its efficient filtering capabilities (Ghosh et al., 1999).The study did not extend to reach the stage of column clogging or need to regenerate the packing media (granular wood charcoal).

The study comprised of monitoring and evaluating the role of biofilm developed on GWC in enhancing the quality of primary wastewater treatment using COD as an indicator. In order to achieve this goal, two bench scale columns were conducted and extended to 96 day. Evaluation of the effluent water quality for irrigation reuse potential was studied with assessed the effects of two particles size (0.5-1 and 1-2mm) of GWC as packing media.

\section{MATERIALS AND METHODS}

\section{Characterization of charcoal}

Commercial wood charcoal was used in the study; grinded and sieved to two target particle size (0.5-1and 1-2 $\mathrm{mm}$ ), then stored in plastic jars. Total carbon, nitrogen and hydrogen content in charcoal were $71.33 \%$, $0.3 \%$, and $2.51 \%$, respectively, and were determined by CHNS analyzer (Saleh et. al., 2016). Some characteristics of GWC were recorded in Table 1.

GWC surface area measurements were obtained from $\mathrm{N}_{2}$ adsorption isotherms at $77 \mathrm{~K}$ using a gas sorption analyzer (Beckman Coulter SA(TM) 3100 Surface Area and Pore Size Analyzer). The samples were outgassed at $473 \mathrm{~K}$ under vacuum for $6 \mathrm{~h}$ previous to conducting adsorption measurements. Specific surface areas were obtained from Brunauer-EmmettTeller (BET) adsorption isotherms equation. The Barrett-Joyner-Halenda (BJH) method was used to determine the pore size distribution from the $\mathrm{N}_{2}$ desorption isotherms (Nader, 2015).

The Fourier transform-infrared (FT-IR) spectra were recorded the range $400-4,000 \mathrm{~cm}^{-1}$ using infrared spectrophotometer; model FT/IR-5300, JASCO Corporation, Japan.

Table1. Some characteristics of GWC used in this study

\begin{tabular}{ccccc}
\hline $\begin{array}{c}\text { Particle size } \\
\mathbf{m m}\end{array}$ & $\begin{array}{c}\mathbf{p H} \\
\left(\mathbf{1 : 2 . 5} \mathbf{H}_{\mathbf{2}} \mathbf{O}\right)\end{array}$ & $\begin{array}{c}\text { Total } \mathbf{C a C O} \\
\mathbf{\%}\end{array}$ & $\begin{array}{c}\text { Surface area } \\
\mathbf{m}^{\mathbf{2}} / \mathbf{g}\end{array}$ & $\begin{array}{c}\text { Total pore volume } \\
\mathbf{m m}^{\mathbf{3}} / \mathbf{g}\end{array}$ \\
\hline $0.5-1$ & \multirow{2}{*}{8.35} & 4.02 & 5.349 & 0.0120 \\
$1-2$ & & & 2.080 & 0.0088 \\
\hline
\end{tabular}


A small amount of powder charcoal sample was amounted on a potassium bromide ( $\mathrm{KBr})$ disc which had been previously scanned as a background in the FT-IR analysis.

Scanning electron microscopy (SEM) was performed by using a Jeol JSM-5300 scanning electron microscope and was operated between 15 and $20 \mathrm{kV}$. Before analysis, samples were gold-coated in a sputter-coating unit (JFC-1100 E). The micrographs were recorded at various magnification scales using photographic techniques to characterize the morphology of charcoal which were dried overnight at approximately $105{ }^{\circ} \mathrm{C}$ under vacuum before SEM analysis. Also, SEM images for GWC samples with biofilm were examined with various magnifications. Samples were taken from upper third of the column after 32 day of the experiment. For this purpose samples were treated with ${ }_{4} \mathrm{~F}_{1} \mathrm{G}(40 \%$ formalin and $25 \%$ glutaraldehyde) for 24 hour in order to fixthe biofilm culture. After fixation, samples dehydrated at $4^{\circ} \mathrm{C}$ through a graded series of ethanol $(30,50,70 \%$ and absolute) three times for $10 \mathrm{~min}$ for each concentration.

\section{Column set-up and operation}

Laboratory experiment was conducted using PVC columns ( $1 \mathrm{~m}$ length, $10 \mathrm{~cm}$ inner diameter) packed with $50 \mathrm{~cm}$ granular wood charcoal as biofiltration media
(Fig. 1-a). Granular wood charcoal was packed in the column with density 0.48 and $0.41 \mathrm{~g} / \mathrm{cm} 3$ for particle size $0.5-1 \mathrm{~mm}$ (column 1)and $1-2 \mathrm{~mm}$ (column 2 ), respectively. Ten $\mathrm{cm}$ layer of crushed and washed stones were placed on top and at the bottom of the columnsin order to improve influent distribution and effluent drain. Columns were loaded discontinuously during experiment time at flow rate $10 \mathrm{~cm}^{3} / \mathrm{min}$. Wastewater feeds were obtained from primary treatment effluent of Alexandria East treatment plant (AETP). Some characteristics of water taken from AETP, used for feeding of biofiltration columns, are presented in Table (2).

\section{Table 2. Characteristics of feeding} wastewater

\begin{tabular}{lc}
\hline Parameter & Concentration range \\
\hline $\mathrm{pH}$ & $7.31-7.92$ \\
$\mathrm{EC}, \mathrm{dS} / \mathrm{m}$ & $2.67-2.93$ \\
$\mathrm{DO}, \mathrm{mg} / \mathrm{L}$ & 0 \\
$\mathrm{COD}, \mathrm{mg} / \mathrm{L}$ & $68.2-229.13$ \\
E. coli, $\mathrm{CFU} / 100 \mathrm{ml}$ & $12 \times 10^{5}-15 \times 10^{5}$ \\
\hline
\end{tabular}

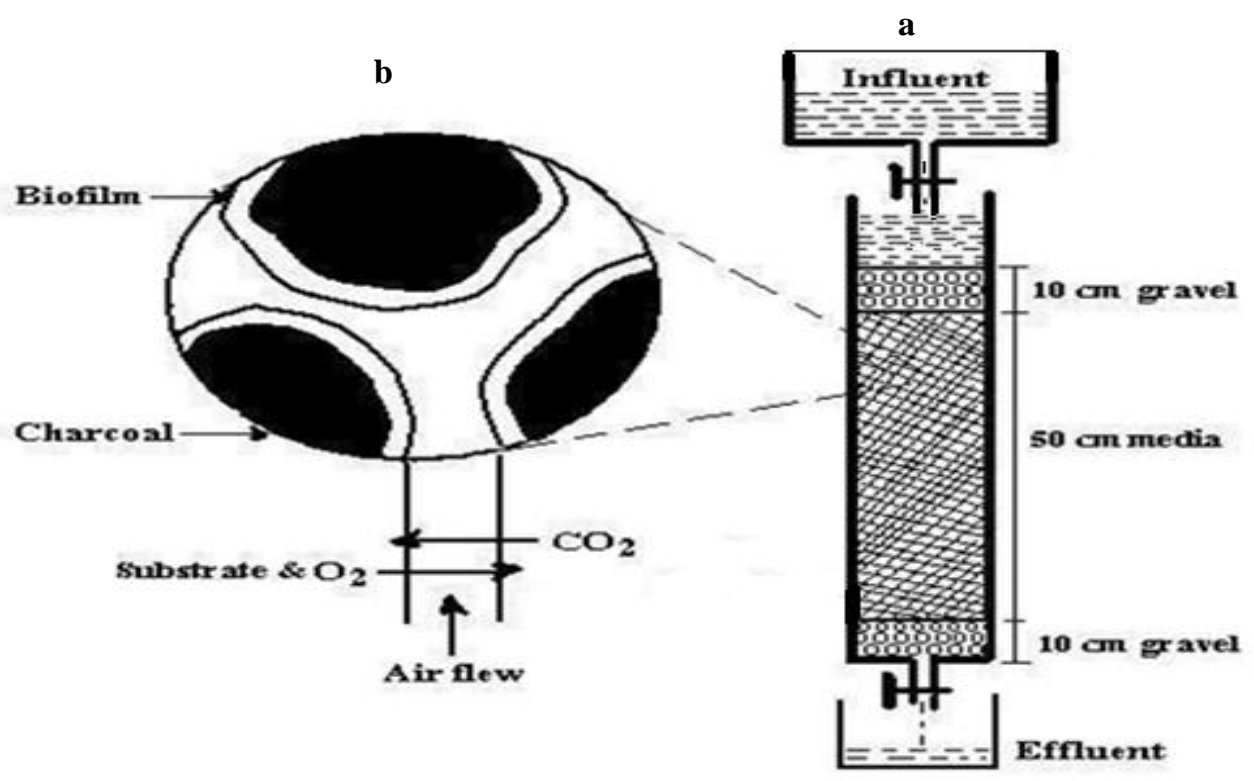

Fig. 1. Schematic of laboratory experiment column 
Hydrodynamic parameters are important in design and operation biofilter column. A constant water head (approx. $20 \mathrm{~cm}$ ) was used above the surface of the biofilter column to control the flow rate as illustrated in Figure (1-a). The flow rate was $10 \mathrm{~cm}^{3} / \mathrm{min}$, corresponded to an average hydraulic loading rate of $7.6 \mathrm{~cm} / \mathrm{h}$. The contact time, usually expressed as empty bed contact time (EBCT), is a key design and operating parameter of a biofilter. Sufficient EBCT is necessary to allow transport and degradation of the pollutant to occur, (Chaudhary et al., 2003). EBCT is simplified, relative measure of chemical residence time in the biofilter column. It would be calculated from equation (1) (Swanson and Loehr, 1997):

$E B C T=\frac{V}{Q}$

Where $\mathrm{V}$ is the biofilter volume $\left(\mathrm{cm}^{3}\right)$ and $\mathrm{Q}$ is influent flow rate $\left(\mathrm{cm}^{3} / \mathrm{min}\right)$. For the two columns, the average EBCT was $6.54 \mathrm{~h}$.

\section{Analytical methods}

Essentially, the methods used were those described in the Standard Methods (STM, 1995). Influent and effluent water of laboratory experiment column were characterized by $\mathrm{pH}$, electrical conductivity (EC), soluble cation and anion, dissolved oxygen (DO), Chemical Oxygen Demand (COD) and Escherichia coli. The oxygen equivalent of organic matter that can be oxidized (COD) is measured by a strong chemical oxidizing agent (potassium dichromate) in an acidic medium, was periodically monitored to evaluate the removal of organic matter by GWC bioflim in the biofilter column. The closed Reflux method that described in the Standard Methods (STM 5220C, 1995) was used. Vessels containing acidified samples with oxidizing agent heated to $150^{\circ} \mathrm{C}$ and reflux (using HACH COD Reactor) for $2 \mathrm{~h}$. After cooling to room temperature, samples titrated with ferrous ammonium sulfate. Removal efficiency is the operating parameter that often used to judge the success of the biofliter, and likely to be of paramount interest to regulator. Removal efficiency $(\mathrm{Re})$ percentage would be calculated as following:

$\operatorname{Re}(\%)=\frac{\left(C_{i}-C_{e}\right)}{C_{i}} X 100$

Where $\mathrm{C}_{\mathrm{i}}$, is the influent concentration $(\mathrm{mg} / \mathrm{L})$ and $\mathrm{C}_{\mathrm{e}}$ is the effluent concentration $(\mathrm{mg} / \mathrm{L})$.

DO was determined by Winkler iodometric titrimetric method and its azide modification (STM 4500-O/C). The $\mathrm{pH}$ and EC values were determined using a glass electrode and conductivity cell (Rhoades, 1996; Thomas, 1996). Compleximetric EDTA titration was employed for determining calcium and magnesium simultaneously and individually (Lanyon and Heald, 1982). Sodium and potassium were determined by flame photometer. The sodium adsorption ratios (SAR) were calculated as:

$$
\mathrm{SAR}=\left[\mathrm{Na}^{+}\right] /\left[\mathrm{Ca}^{2+}+\mathrm{Mg}^{2+}\right]^{1 / 2}
$$

where $\mathrm{Na}^{+}, \mathrm{Ca}^{2+}$ and $\mathrm{Mg}^{2+}$ represent millimolar concentrations $\left(\mathrm{mmol} \mathrm{L}^{-1}\right)$ of respective ions (Essington, 2004).

E. coli enumeration conducted to ensure that water was microbiologically safe at the end of the experiments. E. coli is recommended as an indicator of the potential presence of pathogens (Benham and Zeckoski, 2005; Blaustein et al., 2013) and used as disinfection efficacy for wastewater treatment (Elmund et al., 1999). Oxoid MacConkey Agar No.3 medium was used for enumerating the lactose fermenter E. coli, appearing as pink colonies. E. coli concentrations were determined by inoculating directly onto the surface of MacConkey Agar medium. Inoculated plates were incubated aerobically for 24 hours at temperature of 40 $\pm 1^{\circ} \mathrm{C}$. Culturable $E$. coli were counted by the plate count technique as colony-forming units (CFU) per $100 \mathrm{ml}$ (Guber et al. 2005 and El Refaey, 2008).

Statistical analyses include means for different analytical parameters and correlation coefficients between effluent and influent COD and its removal efficiency with time were estimated.

\section{RESULTS AND DISCUSSION \\ Characterization of GWC}

\section{Surface area and pore analysis}

The BET technique is the most common method for determining the surface area of powders and porous materials due to its simplicity and reasonable forecasts (Giles \&Trivedi, 1969; Girgis et al., 2011). Figure (2) presents $\mathrm{N}_{2}$-adsorption isotherms for the studied GWC with particle size $0.5-1 \mathrm{~mm}$ and $1-2 \mathrm{~mm}$. The $\mathrm{N}_{2}$ adsorbed per gram was plotted versus the relative vapor pressure $(\mathrm{P} / \mathrm{Po})$ of $\mathrm{N}_{2}$ and exhibiting a smoothed lap rising up at high relative pressures with varyingde grees of slope. This revealed a mixed porosity nature (micro/mesoporous).The term "apparent" refers to the wellknown limitation of the BET $\mathrm{N}_{2}$ multi-layer adsorption model in micropores and to the limited accessibility of $\mathrm{N}_{2}$ molecules to narrow micropores (Cazorla- Amoróset al., 1998 and Gibert et.al, 2013). Obviously, the amount of adsorbed $\mathrm{N}_{2}$ at relative pressures (Ps/Po) increased continuously, with higher values in $0.5-1 \mathrm{~mm}$ compared with 1-2 mm particle size (Figure 2). Therefore, the 
apparent specific surface area of $0.5-1$ and 1-2 mm particle sizes were 5.349 and $2.080 \mathrm{~m}^{2} / \mathrm{g}$, respectively due to different in particle size (Table 1). Total pore volume of $0.5-1 \mathrm{~mm}$ particle size $\left(0.0120 \mathrm{~mm}^{3} / \mathrm{g}\right)$ was relatively higher than $1-2 \mathrm{~mm}$ particle size $\left(0.0088 \mathrm{~mm}^{3} /\right.$ g).

The International Union of Pure and Applied Chemistry (IUPAC) categorized the pore size mainly into three types: micropore (poresize $<2 \mathrm{~nm}$ ), mesopore $(2-50 \mathrm{~nm}$ ), and macropore (poresize $>50 \mathrm{~nm}$ ) (Williams and Reed, 2006). Desorption BJH pore size distribution for the two particles size $(0.5-1 \mathrm{~mm}$ and $1-2 \mathrm{~mm})$ of GWC were identified in Table (3). Pore size distribution in $0.5-1 \mathrm{~mm}$ was similar to $1-2 \mathrm{~mm}$ except in the range less than $6 \mathrm{~nm}$. Whereas, the pore size distribution that related to microporous formation in 0.5 $-1 \mathrm{~mm}$ particle $(21.02 \%)$ was higher than $1-2 \mathrm{~mm}$ particle size (15.22\%). Micropores contribute mainly to surface area, while macropores contribute as a channel to micropore surfaces (Yahya et. al., 2015).

\section{FTIR analysis}

FTIR analysis was used to determine the availability of certain surface functional groups as part of the structure of any sorbents. The FTIR spectra of GWC are presented in Fig. (3). The FTIR spectrum of GWC exhibits more intensive bands at the following wavenumbers: $3419.56,1599.84,1438.80,1072.35$, 781.12 and $510.14 \mathrm{~cm}^{-1}$, corresponds mainly to the presence $\mathrm{O}-\mathrm{H}$ (hydroxyl), asymmetric $\mathrm{C}-\mathrm{H}$ and aromatic C-C O-O-H bend (carboxylic acids), C-N stretch (aliphatic amines), C-H aromatic and alkyl halide stretch (e.g, C-Cl), respectively (Saleh et.al, 2015 and El Refaey, 2016).

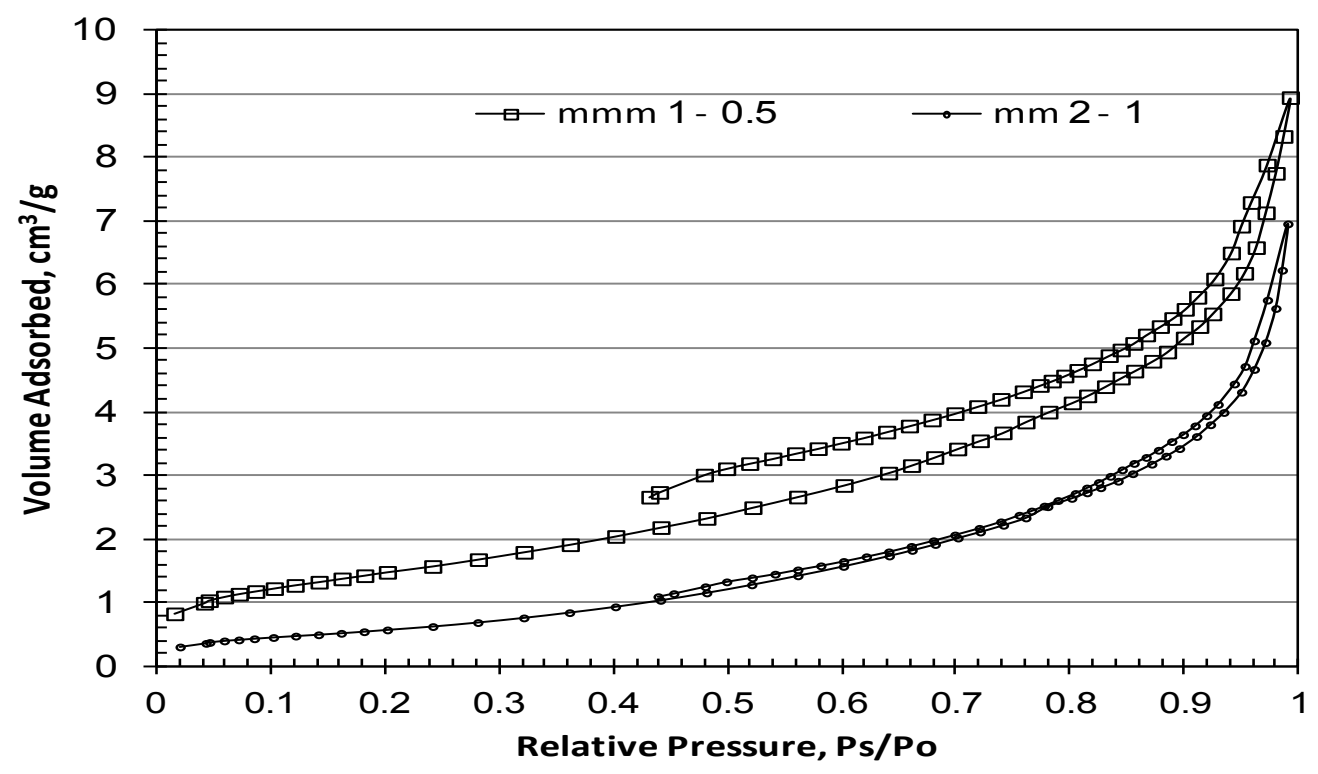

Fig. 2. $\mathrm{N}_{2}$-adsorption isotherms of GWC with two different particle size(0.5-1 and 1-2mm)

Table 3. Desorption Barrett-Joyner-Halenda (BJH) pore size distribution of two particle size $(0.5-1$ and $1-2 \mathrm{~mm})$ of GWC used in the study

\begin{tabular}{ccccc}
\hline & \multicolumn{5}{c}{ Pore volume } \\
\cline { 2 - 5 } Pore diameter range $\mathbf{n m}$ & $\mathbf{2} \mathbf{( 0 . 5}-\mathbf{~} \mathbf{m m})$ & $\mathbf{~}$ & $\mathbf{( 1 - 2 ~ \mathbf { ~ m m } )}$ \\
\cline { 2 - 5 } & $\mathbf{m l} / \mathbf{g}$ & $\mathbf{\%}$ & 0.00135 & $\mathbf{\%}$ \\
\hline$>80$ & 0.00104 & 39.44 & 0.00411 & 12.95 \\
$20-80$ & 0.00447 & 6.71 & 0.00071 & 39.29 \\
$16-20$ & 0.00076 & 6.24 & 0.00074 & 6.75 \\
$12-16$ & 0.00071 & 5.33 & 0.00062 & 7.10 \\
$10-12$ & 0.00060 & 4.56 & 0.00053 & 5.95 \\
$8-10$ & 0.00052 & 7.51 & 0.00080 & 5.05 \\
$6-8$ & 0.00085 & 21.02 & 0.00159 & 7.63 \\
$<6$ & 0.00238 & & & 15.22 \\
\hline
\end{tabular}




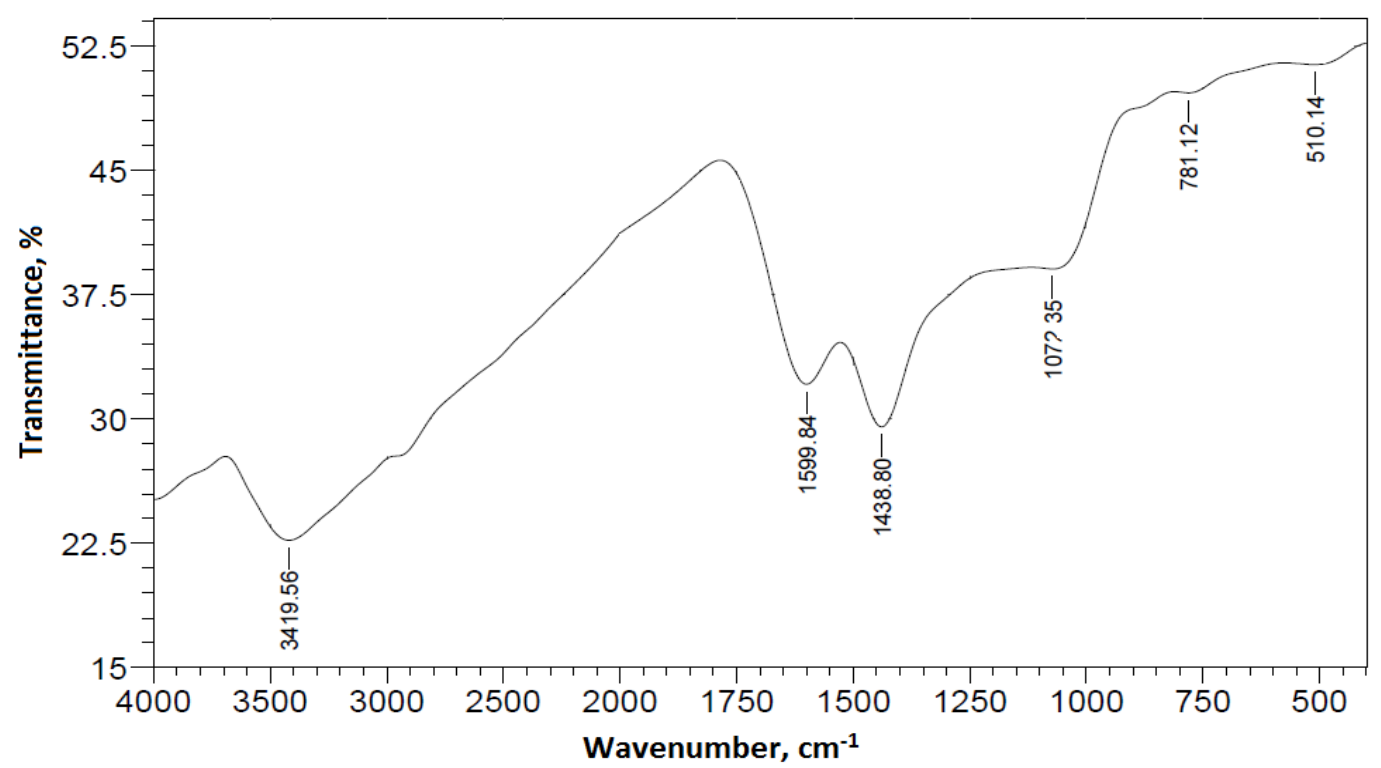

Fig. 3. FTIR spectra of the granular wood charcoal (GWC)

\section{Scanning electron microscopy (SEM)}

The surface structure of porous GWC was characterized by SEM (Fig 4). SEM produces an actual clear image, which is useful for obtaining the topographical and elemental information of the solids with a virtually large depth of field, allowing different specimen parts to stay in focus at a time.(Gupta and Rastogi, 2008). However, the SEM technique also has limitations on its lowest detectable particle size. Porous structure is a factor that determines to a great extent both the rate and degree of bioregeneration in biofilter system (Klimenko et al., 2002). Actual porous structure of GWC was observed in SEM (Fig $4 \mathrm{a}$ and b). Also, GWC biofilm was confirmed by SEM examination, which revealed a complex morphological diversity composed of diverse of substrates and microorganisms in voids and channels of GWC(Fig. $4 \mathrm{c}$ and d) and on irregular surfaces of the GWC (Fig. 4 e and f). Also, organic filaments closely similar to fungal hyphae were found to be a common feature through out the GWC surface (Fig. $4 \mathrm{~g}$ and $\mathrm{h}$ ).

\section{COD removal and biofilm efficiency}

Two biofilter column were characterized by start-up period of 96 days for column (1) and column (2) with changes of organic load as chemical oxygen demand (COD) (Fig.5A and B). Concentration of effluent COD has been fluctuated with every new batch of influent, giving correlated and significant relationship between them (Fig. 6). COD tended to decrease to less than 13, and $16 \mathrm{mg} / \mathrm{L}$ for column (1) and (2), respectively (Fig. 5-A and B). As well, the surface area, irregular creviced, porous particle shape (as seen in Fig. 4-a and b) and slightly electro-positively charged of GWC can absorb specific water contaminates such as dissolved organic matter (Scholz and Martin, 1997). Dussert and Van Stone (1994) and Rhim (2006) reported that during the transit through the percolator, the wastewater is purified by processes of physical adsorption, concurrent adsorption/biological degradation and biological degradation, respectively. Simpson (2008) defined the process of breaking down and removing adsorbed substances by the attached microbial as 'biodegradation'.Microorganism's masses attached onto the GWC as biofilm oxidize most of the organics and use it as an energy supply and carbon source, as illustrated in Fig. (1-b).The processes started with an acclimation period. Acclimation period is the biofilter start-up time during which removal efficiencies progressively increase until they achieve a sustained maximum value. This phenomenon occurs and it is often measured as the time necessary to reach $40-90 \%$ or more of some maximum removal capacity (Swanson and Loehr, 1997;Rhim, 2006). As shown in figures (5- A and -B) with smoothing, removal percent tends to significantly increase with time to reach 91.36and $87.69 \%$ for column (1) and (2)after 96 day, respectively. The slight increase in the removal efficiency in column (1) suggests that it can be explained by high surface area of particle size for column (1) than in column (2). Liang et. al.(2007) suggested that decreasing of the particle size causes in more substrate diffusing across the biofilm, and increases the ratio of adsorption rather than biodegradation. 

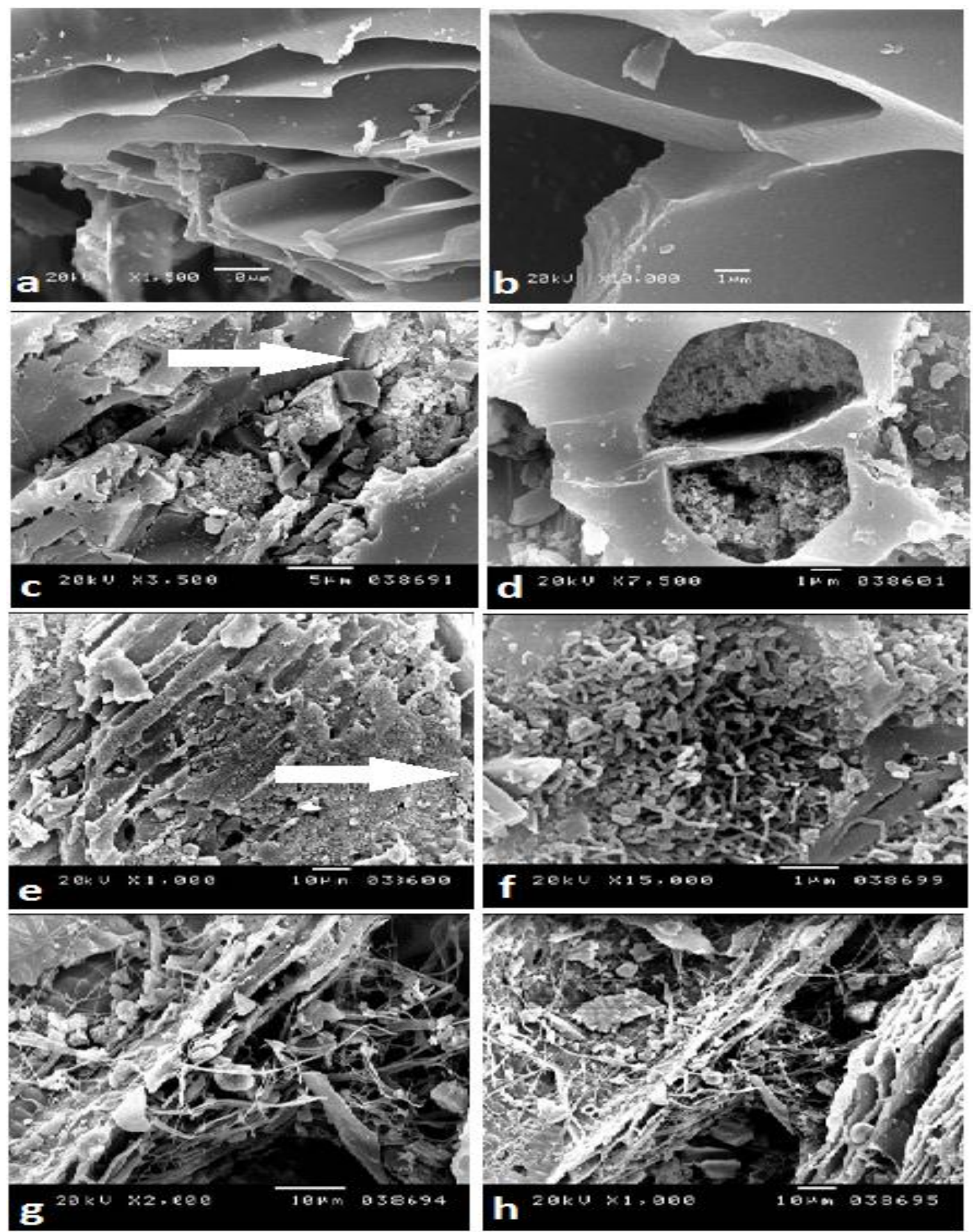

Fig. 4. SEM imagesshowing porous structure of granular wood charcoal (a and b), diverse of substrates and microorganisms in the voids of the porous (c and d), on irregular surface (e and $f$ ) and ( $g$ and $h$ ) organic filaments closely similar to fungal hyphae observed on a GAC sample collected from the upper third of the column after 32 days of the experiment 

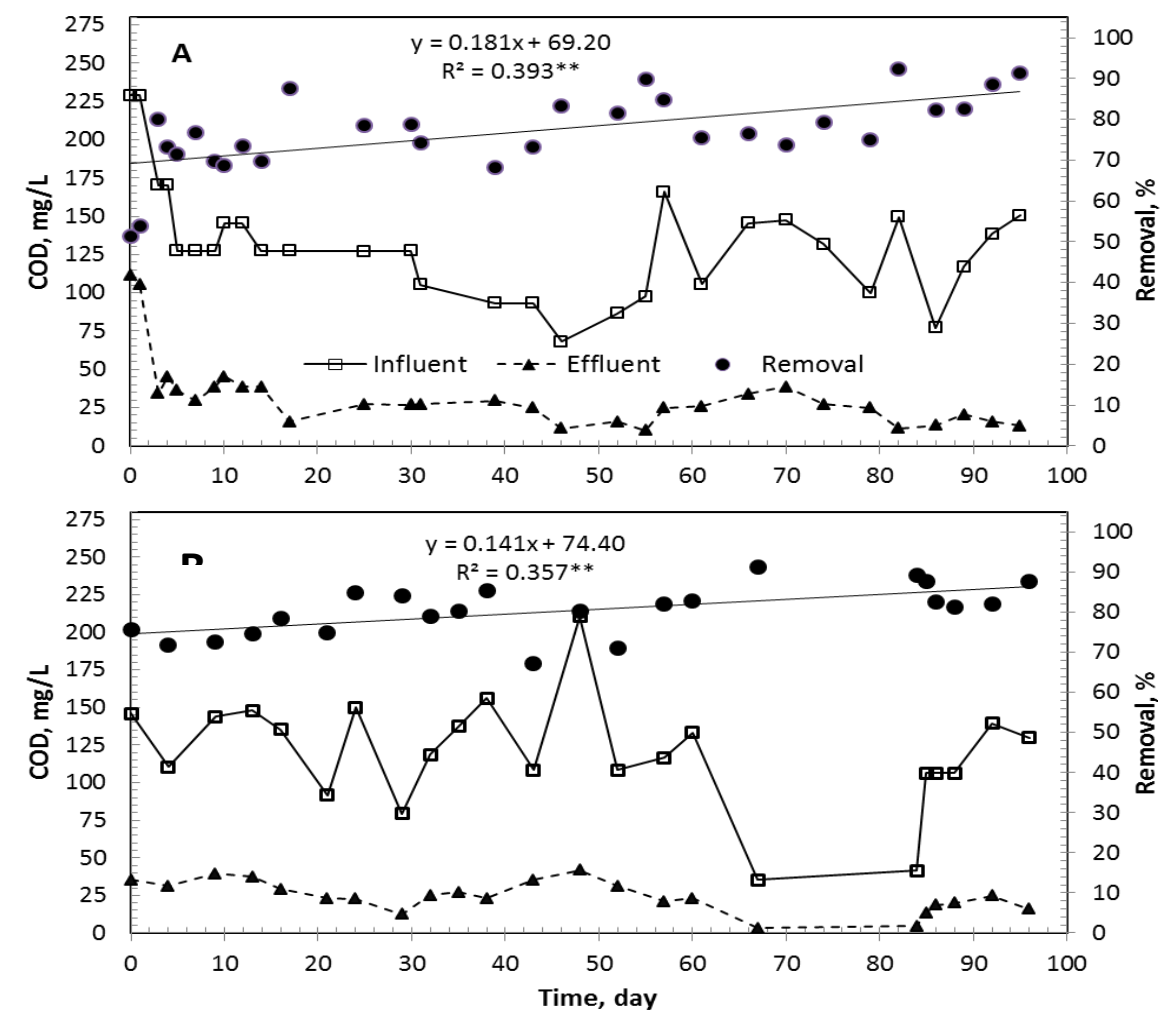

**: significant at the 0.01 probability level

Fig. 5. Changes in chemical oxygen demand (COD) and removal efficiency of the influent and effluent for column (1) and (2) with time

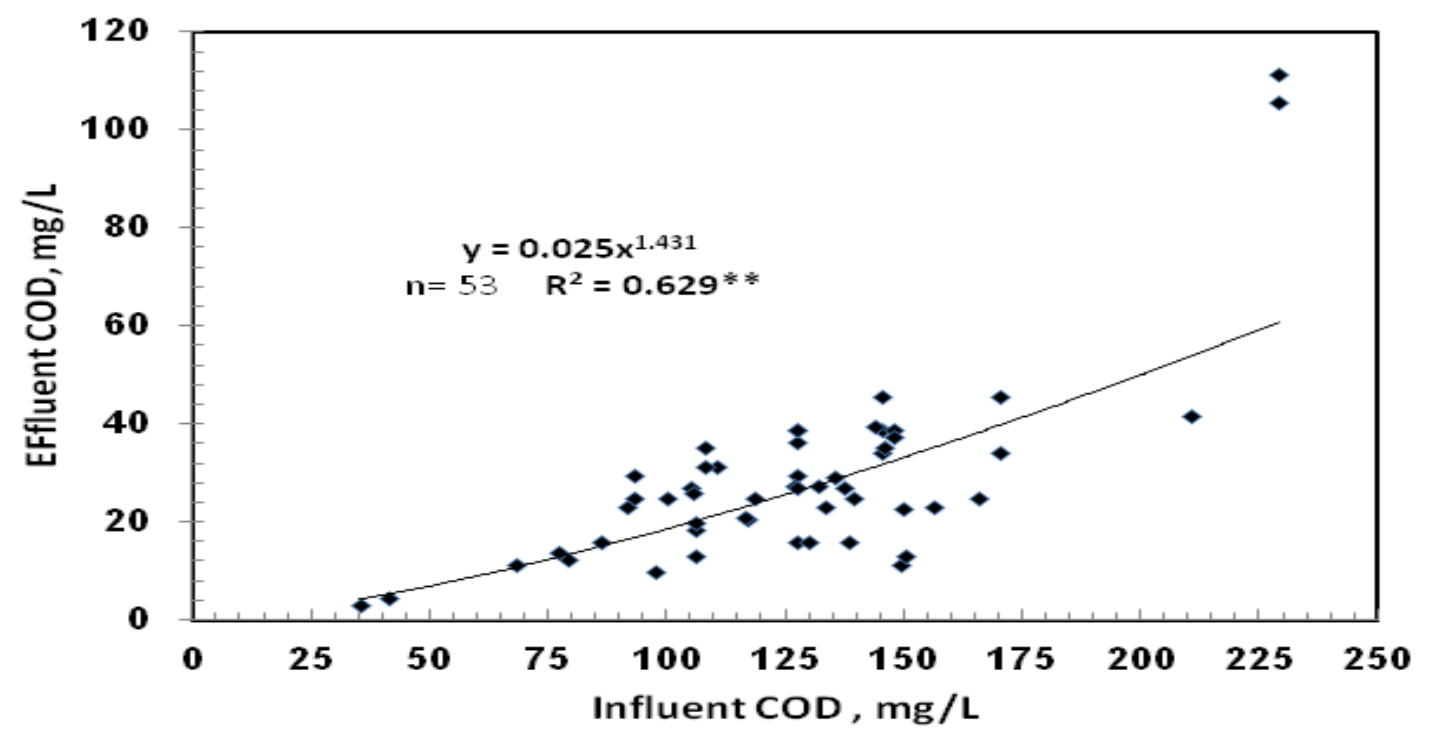

**: significant at the 0.01 probability level

Fig. 6. Relationship between effluent and influent of the biofilter columns expressed as chemical oxygen demand (COD) 


\section{Evaluation of effluent qualityand irrigation reuse potential}

Table (4) shows effluent characteristics for column (1) and (2) with two different particle size 0.5-1 mm and $1-2 \mathrm{~mm}$, respectively. Two keys for soil and water related constraints that need to be addressed when dealing with irrigating reuse are salinity and sodicity. According to irrigation water quality guidelines by Ayers and Westcot (1985), the available effluent characteristics can be categorized as slight to moderate degree of restriction use for both columns. Wastewater reuse application usually governed by the needed to protect public health and the environment. Final effluent of COD was in acceptable level $(<60 \mathrm{mg} / \mathrm{L})$ of the Egyptian law 48/1982, where the results were 13 and 16 $\mathrm{mg} / \mathrm{L}$ for column (1) and (2), respectively. E. coli concentrations were $15 \times 10^{2}$ and $11 \times 10^{3} \mathrm{CFU} / 100 \mathrm{ml}$ for column (1) and (2), respectively. Although E. coli removal was more than $99 \%$ for both columns, slight increase in column $1(99.86 \%)$ was found than in column 2 (99.20), but still beyond WHO guidelines for the use of wastewater in agriculture and aquaculture $\left(10^{3}\right.$ fecal coliform (FC) $100 \mathrm{ml}^{-1}$ ). Addition disinfection step may be needed after biofiltration columns. Most rivers in Europe have mean FC counts of $10^{3}-10^{4} 100 \mathrm{ml}^{-1}$, and yet there are no restrictions on the use of such water (Shuval and Fattal, 2003). More relaxed guideline of $10^{4}$ FC $100 \mathrm{ml}^{-1}$ has been suggested (Carr et al., 2004), but should be supplemented by other health protection measures. Thus safe irrigation reuse of biofiltration system can cost- effectively attained through the acceptable level of risks developed in practices.

Table 4. Final Effluent characteristics of column (1) and (2) with two different particle size $0.5-1$ and $1-2 \mathrm{~mm}$, respectively

\begin{tabular}{lccc}
\hline \multirow{2}{*}{ parameter } & & \multicolumn{2}{c}{ Effluent } \\
\cline { 2 - 4 } & unit & column (1) & column (2) \\
\hline $\mathrm{pH}$ & & 8.05 & 8.09 \\
$\mathrm{EC}$ & $\mathrm{dS} / \mathrm{m}$ & 3.13 & 3.17 \\
$\mathrm{DO}$ & $\mathrm{mg} / \mathrm{L}$ & 2.70 & 2.50 \\
$\mathrm{COD}$ & $\mathrm{mg} / \mathrm{L}$ & 13.00 & 16.00 \\
$\mathrm{Na}^{+}$ & $\mathrm{mg} / \mathrm{L}$ & 16.52 & 16.96 \\
$\mathrm{~K}^{+}$ & $\mathrm{meq} / \mathrm{L}$ & 2.05 & 2.18 \\
$\mathrm{Ca}^{++}$ & $\mathrm{meq} / \mathrm{L}$ & 3.00 & 3.25 \\
$\mathrm{Mg}^{++}$ & $\mathrm{meq} / \mathrm{L}$ & 5.77 & 6.60 \\
$\mathrm{HCO}^{+}{ }_{3}$ & $\mathrm{meq} / \mathrm{L}$ & 5.75 & 5.80 \\
$\mathrm{Cl}$ & $\mathrm{meq} / \mathrm{L}$ & 20.00 & 20.00 \\
$\mathrm{SAR}$ & & 7.89 & 7.64 \\
E. coli & $\mathrm{CFU} / 100 \mathrm{ml}$ & $15 \times 10^{2}$ & $11 \times 10^{3}$ \\
\hline
\end{tabular}

\section{CONCLUSION}

The study investigated the effect of biofilm developed on two different particle sizes $(0.5-1 \mathrm{~mm}$ column (1) and 1-2 mm column (2)) of granular wood charcoal in enhancing the primary wastewater treatment. SEM images confirmed that the bioflm of diverse microorganisms is found on surface, voids and channels of GWC. COD in final effluent decreased to 13, and 16 $\mathrm{mg} / \mathrm{L}$ for column (1) and (2), respectively after 96 days with slight increase in the removal efficiency of column (1). Characterization with surface area and pore size distribution gave the different properties of the two particle sizes of GWC and could explain the difference in removal of organic matter. Evaluation of effluent quality and irrigation reuse potential were performed at the end of the experiments. The final effluent characteristics can be categorized as slight to moderate degree of restriction use for both columns. E. coli removal was more than $99 \%$ for both columns with slight increase in column $1(99.86 \%)$ than in column 2 $(99.20 \%)$, but still beyond WHO guidelines.Addition disinfection may be need after biofiltration columns.

\section{REFERENCES}

Agbanobi, R. O. 1999. Using granulated wood charcoal as filter medium. Journal Environmental Qualilty. 28:10381040.

Aktaş, ö. and F. Çeçen. 2007. Bioregeneration of activated carbon: A review. International Biodeterioration\& Biodegradation 59: 257-272.

Ayers, R. S., and D. W. Westcot. 1985. Water quality for Agriculture, FAO Irrigation and drainage paper 29, Rev. 1., Food and Agriculture Organization of the United Nationals, Rome, Italy.

Benham, B. L. and S. C. Zeckoski. 2005. TMDLs (Total Maximum Daily Loads) for bacteria impairments. Virginia Cooperative Extension, Biological Systems Engineering, publication: 442-555. available at http://pubs.ext.vt.edu/442/442-555/442-555.pdf.

Blaustein, R.A., Y. Pachepsky, R.L. Hill, D.R. Shelton and G. Whelan. 2013. Escherichia coli survival in waters: Temperature dependence. Water Research 47: 569-578.

Buchanan, W., F.Roddick, N. Porter. 2008. Removal of VUV pretreated natural organic matter by biologically activated carbon columns. Water Res. 42: 3335-3342.

Carr, R. M. , U. J. Blumenthal and D. D. Mara. 2004. Health guidelines for the use of wastewater in agriculture: Developing realistic guidelines. In Scott, C. A., N. I. Faruqui and L. Raschid-Sally. Wastewater Use in Irrigation Agriculture. CAB International in association with the International Water Management Institute and the International Development Research Center. pp. 41-58. 
Cazorla-Amorós, D., J. Alcañiz-Monge, M.A.de la Casa-Lillo, L.A. Linares-Solano. 1998. $\mathrm{CO}_{2}$ as an adsorptive to characterize carbon molecular sieves and activated carbons. Langmuir 14: 4589-4596.

Chaudhary, D. S., S.Vigneswaran, H. Ngo, W. G. Shim and H. Moon. 2003. Biofilter in Water and Wastewater Treatment. Korean J. Chem. Eng., 20: 1054-1065.

Derlon, N. , N. Koch , B. Eugster, T. Posch , J. Pernthaler, W. Pronk , E. Morgenroth. 2013. Activity of metazoa governs biofilm structure formation and enhances permeate flux during Gravity-Driven Membrane (GDM) filtration. WaterResearch 47:2085-2095

Dussert, B. and G. Van Stone. 1994. The biological active carbon process for water purification. Water Eng. Manage. 141: 22-24.

El Refaey, A. A. 2008. Fate of indicator microorganism Escherichia coli in drains and canals-irrigation reuse perspective. Ph D thesis, Univ. Alexandria.

Elmund, G. K., M. J. Allen, and E. W. Rice. 1999. Comparison of Escherichia coli, total coliform, and fecal coliform populations as indicators of wastewater treatment efficiency. Water Environ. Res. 71:332-339.

El-Refaey, A. A. 2016. Comparative performance of cement kiln dust and activated carbon in removal of cadmium from aqueous solutions. Water Science \& Technology, 73: 1691-1699.

Emelko, M. B., P.M. Huck, B. M. Coffey, and E. F. Smith. 2006. Effects of media, backwash, and temperature on full-scale biological filtration. J. Am. Water Works Assoc. 98: 61-73.

Essington, M. E. 2004. Soil and Water Chemistery. An integrative approach. CRC Press, Boca Raton, FL.

Ghosh, U., A. Weber,J.Jensen andJ.Smith. 1999. Granular activated carbon and biological active carbon treatment of dissolved and sorbed polychlorinated biphenyls. Water Environ. Res. 71: 232-240.

Gibert, O., B. Lefèvre, M. Fernández , X. Bernat, M. Paraira, M. Calderer, X. Martínez-Lladó. 2013. Characterising biofilm development on granular activated carbon used for drinking water production. Water Research, 47:11011110.

Giles, C. H. andA. S.Trivedi. 1969. A rapid method of determination of specific surface of solids by dye adsorption London: Chem Ind., 1426-1427.

Girgis, B.S.,A.M.Soliman, and N.A.Fathy.2011. Development of micro-mesoporous carbons from several seed hulls under varying conditions of activation. Microporous and Mesoporous Materials 142: 518-525.

Guber, A. K., D. R. Shelton and Ya. A. Pachepsky. 2005. Effect of manure on Escherichia coli attachment to soil. J. Environ. Qual. 34:2086-2090.

Gupta, V. K. andA.Rastogi. 2008.Biosorption of lead from aqueous solutions by green algae Spirogyra species: kinetic and equilibrium studies. Journal of Hazardous Materials 152: 407-414.
Huang, W.J. and L.Y. Chen. 2004. Assessing the effectiveness of ozonation followed by GAC filtration in removing bromate and assimilable organic carbon. Environ. Technol. 25: 403-412.

Jowett, E. Craig and Michaye L. McMaster. 1995. On-site wastewater treatment using unsaturated absorbent biofilters. Journal Environmental Qualilty. 24:86-95.

Kasuga, I., D. Shimazaki, S. Kunikane. 2007. Influence of backwashing on the microbial community in a biofilm developed on biological activated carbon used in a drinking water treatment plant. Water Sci. Technol. 55:173-180.

Klimenko, N., M. Winther-Nielsen, S. Smolin, L. Nevynna, and J. Sydorenko. 2002. Role of the physico-chemical factors in the purification process of water from surfaceactive matter by biosorption. Water Research 36: 51325140.

Lanyon, L. E. and W. R. Heald. 1982. Magnesium, calcium, strontium and barium. In: A. L. Page, R.H. Miller and D.R. Keeny. (eds.). Methods of Soil Analysis, Part 2. Chemical and Microbiological Properties. Agronomy Monograph No. 9 (2nd Edition). ASA-ASSA, Madison, USA.

Lazarova, V. and J. Manem. 1995. Biofilm characterization and activity analysis in water and wastewater treatment. Water Research, 29: 2227-2245.

Liang, C., P. Chiang and E. E Chang. 2007. Modeling the behaviors of adsorption and biodegradation in biological activated carbon filters. Water Research, 41: 3241 - 3250.

Masters, G.M. 1998. Introduction to Environmental Engineering and Science, Ed.2, Prentice Hall, New Jersey.

Metcalf and Eddy, Inc. 2003. Wastewater engineering: Treatment, and Reuse. McGraw-Hill, Inc., New York.

MWRI, Ministry of Water Resources and Irrigation, Egypt. 2014. Water Scarcity in Egypt. Available atwww.mfa.gov.eg/.../Egypt\%20Water\%20Resources\%20 Paper_2014.pdf (accessed at 25/8/2016).

Nader, M.2015 Surface area: Brunauer-Emmett-Teller (BET). In: Progress in Filtration and Separation (S. Tarleton, ed.).Academic Press, London, UK, pp. 585-608.

Putz, A.R.H., D.E. Losh and G.E. Speitel. 2005. Removal of nonbiodegradable chemicals from mixtures during granular activated carbon bioregeneration. J. Environ. Eng. 131:196-205.

Rhim, J. 2006. Characteristics of adsorption and biodegradation of dissolved organic carbon in biological activated carbon pilot plant. Korean J. Chem. Eng. 23: 3842.

Rhoades, J. D. 1996. Salinity: Electrical conductivity and total disolved solids. P. 417-435. In D.L. Sparks et al. (ed.) Methodes of soil analysis Part3: Chemical methods. SSSA, Madison, WI.

Saleh, M. E., , A. A. El-Refaey and A. H. Mahmoud. 2015. Effectiveness of sunflower seed husk biochar for removing copper ions from wastewater: a comparative study. Soil \&Water Research 11: 53-63. 
Scholz, M. and R. Martin. 1997. Ecological equilibrium on biological active carbon. Water Res. 31 (12), 2959-2968.

Seredyńska-Sobecka B., M. Tomaszewska, M. Janus and A. W. Morawski. 2006. Biological activation of carbon filters. Water Research 40: 355 - 363.

Shuval, H. and B. Fattal. 2003. Control of pathogenic microorganisms in wastewater recycling and reuse in agriculture. In D. Mara and N. Horan (eds.) Handbook of water and wastewater microbiology. Academic Press. Amsterdam.

Simpson, D. R. 2008. Biofilm processes in biologically active carbon water purification. Water Research, 42:2839 2848.

Standard Methods (STM), American Public Health Association (APHA). 1995. Standard methods for the examination of water and wastewater, 19th ed. American Public Health Association, Washington, DC.

Swanson, W. J. and R. C. Loehr. 1997. Biofiltration: fundamentals, design and operations principles and applications. Journal environmental Engineering. 123: 538-546.

Thomas, G. W. 1996. Soil pH and soil acidity. P. 475-490. In D.L. Sparks et al. (ed.) Methodes of Soil Analysis Part3: Chemical methods. SSSA Book Ser 5. SSSA, Madison, WI.
Urfer, D. and P.M Huck. 2001. Measurement of biomass activity in drinking water biofilters using a respirometric method. Water Research, 35: 1469-1477.

Velten, S., M. Boller, O. Köster, J. Helbing, H.U. Weilenmann andF.Hammes. 2011. Development of biomass in a drinking water granular active carbon (GAC) filter. Water Research, 45: 6347-6354.

Williams, P. T. and A. R. Reed. 2006. Development of activated carbon pore structure via physical and chemical activation of biomass fibre waste. Biomass Bioenergy, 30:144-52.

Yahya, A. M.,Z. Al-Qodah and C.W. Z.Ngah. 2015. Agricultural bio-waste materials as potential sustainable precursors used for activated carbon production: A review. Renewable and Sustainable Energy Reviews 46: 218-235.

Zheng, L., N. Gao, Y. Deng, E. Du, M.Sui and S. Liu. 2011. The effect of backwashing in the structure of microbial community on biological activated carbon (BAC) in a water treatment plant. Fresen. Environ. Bull. 20:17411748.

Zhu, I.X., T. Getting and D.Bruce. 2010. Review of biologically active filters in drinking water applications. J. Am. Water Works Assoc. 102: 67-77. 


\section{الملخص العربي}

\section{دور الاغثية الحيوية المتكونة على سطح حبيبات الفحم المصنع من الاخثاب فى تحسين المعالجة}

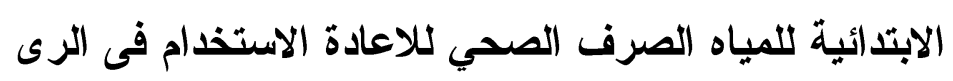

أحمد عبد الخالق الرفاعى لاعلى

الميكروسكوب الالكترونى، وتاكيــــ دورهـــــــن خـلال

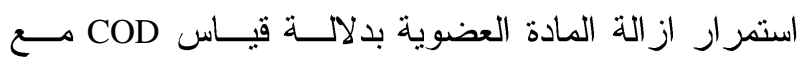

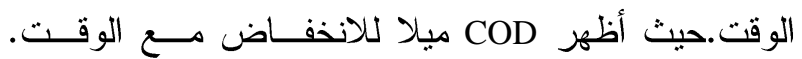

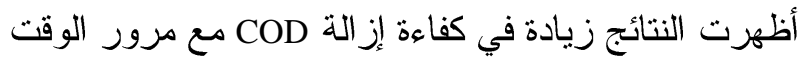

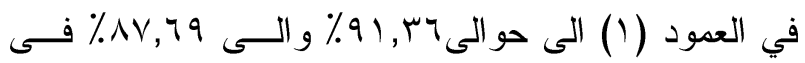

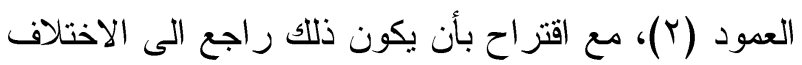
فى السطح النوعى للحجمين المستخدمين من حبييات الفحم. وتم تقييم المياه الخارجه من عملية المعالجــة، واظهـرت التهرت امكانية إعادة استخدامها في الري مع وجود محاذير بسيطه الى معتدلة من حيث معايير الملوحة والصــودية. ولتاكيــد

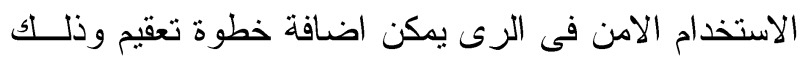

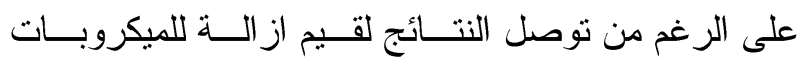
(E. coli) التجربة ان عملية الترشيح البيولوجية بمكن أن تكون خيار

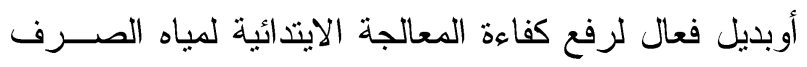
الصحى.

الكلمات الكثافة: حبيبات الفحم المصنع من الاخشاب-

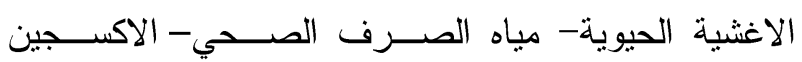
الكيمائى المستهلاك.
تز ايد ندرة المياه يتطلب إعادة الاستخدام الآمـن للميــاه لتضييق الفجوة بين العرض و الطلب على مياه الري. تهدف

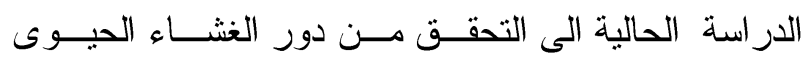
المتكون على سطح حبييات الفحم المصنع مـن (Biofilm)

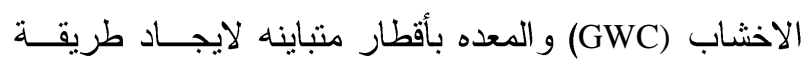

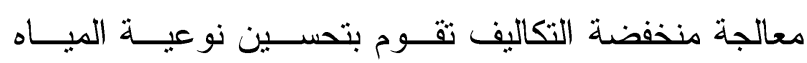

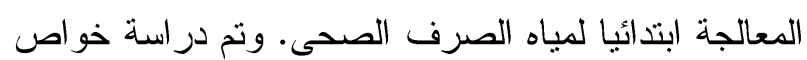
حبيبات الفحم من حيث السطح النـوعى وحجــ المســام

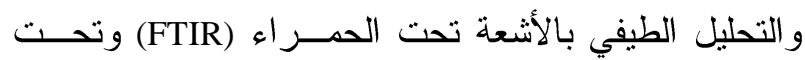

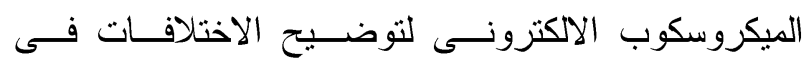

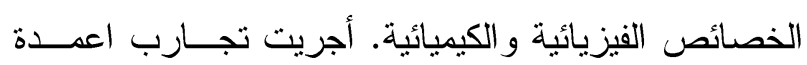

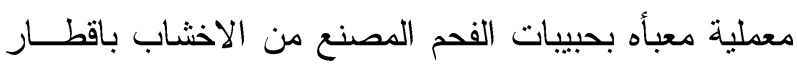

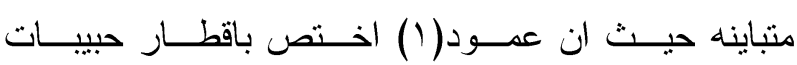
0, • - امم وعمود(r) اختص باقطار حبييات ا-r مم وتم

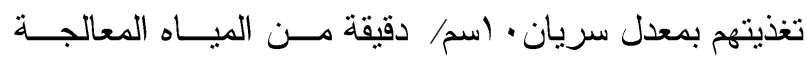

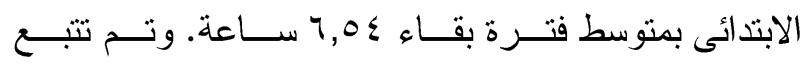
الاكسجين المستهللك كيميائيا (COD) للميــاه الخارجـــة مــن

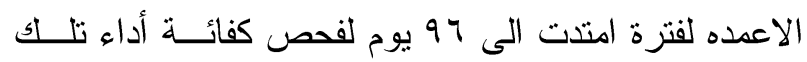

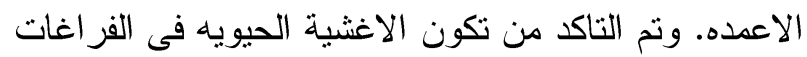

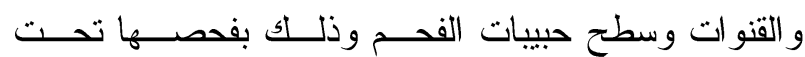

